\title{
Impact of Training Programme on Knowledge Gain of Tomato Growers in Meghalaya
}

\author{
E. K. Marbaniang ${ }^{1 *}$, J. K. Chauhan ${ }^{2}$ and Pynbianglang Kharumnuid ${ }^{3}$ \\ ${ }^{1}$ Krishi Vigyan Kendra, West Khasi Hills, Nongshillong, (Meghalaya), India \\ ${ }^{2}$ School of Social Sciences, College of Post-Graduate Studies in Agricultural Sciences (CAU), \\ Umiam, Meghalaya, India \\ ${ }^{3}$ Central Potato Research Institute, Shimla, India \\ *Corresponding author
}

\section{A B S T R A C T}

\section{Keywords}

Tomato Growers,

Article Info

Accepted:

15 December 2020

Available Online:

10 January 2021

An investigation on impact of training among one hundred twenty trainees was purposively under taken in twelve cluster villages under two Blocks of West Khasi Hills district in Meghalaya during the year 2017-18in order to study the knowledge gain of the tomato growers through training and the suggestions for improvement. A knowledge test during off campus training programme on organic cultivation of tomato was conducted for two groups of 60 trainees each and primary data was collected through personal interview using structured interview schedule. Results revealedthat 45.83 per cent of the trainees belonged to middle age group (35-55 yrs),majority of them $(89.16 \%)$ were married, and $41.66 \%$ studied upto primary school with large family size (42.50\%).Majority $(62.50 \%)$ had no extension contact and $60.83 \%$ had medium economic motivation. About 52.50 percent participated in training mainly for crop improvement and knowledge gain of the trainees were on seed treatment $(68.33 \%)$ followed by improved varieties $(49.16 \%)$ and soil treatment $(47.50 \%)$. More than half suggested more importance be given to training demonstration classes especially on insect and disease management for training improvement.

\section{Introduction}

Meghalaya has a total land area of around 22,430 square kilometers. Tomato covers an area of 1965 hectares with a production of $30224 \mathrm{MT}$ and productivity $15492 \mathrm{kgs} / \mathrm{ha}$ in the state. (Source: Directorate of Economics and Statistics, Government of Meghalaya, 2012-13). Tomato is one of the main cash crops growing extensively about 54.00 hectare area in West Khasi Hills with a production of 783 metric tonnes (GoM, 2018). This crop has been grown in cluster of villages mainly for supply to nearby state of Assam during off season fetching a very high price for the farmers and even sold to the local market.

The farmers had been growing the crop for many years with non-judicious use of chemical pesticides to control the insect pests and fungal diseases such as early and late 
blight diseases of tomato. With the current importance of organic farming, a need for imparting training to the tomato growers is felt with the motive to reduce the cost of cultivation, increasing the farm income and ultimately to produce a good quality crop free from chemical fertilizers and pesticides.

Knowledge gain was the quantity of information gained by the respondent before and after exposure of intervention.

Knowledge was the treasure of truth and facts and was a pre- requisite for performing any activity with perfection. It was an inevitable pre-requisite input for efficient management (Helen and Khaleel, 2009). Thus, the present study was conducted with the objectives to study the knowledge gain of the tomato growers through training and the suggestions for improvement.

\section{Materials and Methods}

The present study was undertaken purposively among one hundred and twenty tomato growers in twelve cluster villages under two Blocks of West Khasi Hills district in Meghalaya during the year 2017. Off campus training programme is usually conducted in the farmers' village itself with a training duration of 5 days. Two such off campus training programmes were conducted for two groups of 60 trainees each and thus a knowledge test was undertaken for these trainees.

A pre-test knowledge on organic cultivation of tomato before training programme and post-test knowledge after training comprising of questions on the 11 technology practices for these two groups were collected by contacting growers personally with the help of pretested semi-structured interview schedule. Training methods used were lecture with poster, power point presentation, videos and method demonstration. Hence, gain in knowledge was calculated from the difference of scores obtained in pre and post knowledge test of the trainees. Likewise, the suggestions from the trainees were recorded for bringing further improvement in the training. The data were tabulated and analyzed using frequency, percentages, mean, standard deviation and ranking.

\section{Results and Discussion}

\section{Profile of the tomato growers}

Results from Table 1 showed that 45.83 per cent of the trainees belonged to middle age group (35-55 yrs) followed by 33.33 percent under young age group (upto 34 yrs) and majority of them $(89.16 \%)$ were married. Less than half of the trainees (41.66\%) studied upto primary school with large family size $(42.50 \%)$ and thus impart of training for the tomato growers is very much essential to improve the overall knowledge, skill and attitude of the farmers in which the findings were in line with the research results of Fakoya et al., (2003) and Manay and Farzana (2000). It was also reported that 27.50 percent of the trainees had medium level of annual income followed by high annual income (26.66\%) which was due to the adoption of tomato cultivation in the area.

Table 1 also indicated that more than half of the trainees $(53.33 \%)$ had marginal land holding with majority of them $(62.50 \%)$ had no extension contact while trainees of about 66.66 percent had no membership in any organisation. About 60.83 percent of trainees had medium economic motivation while 33.33 per cent of them had high risk orientation which occurred due to higher returns received from tomato cultivation and more than half of the trainees $(55.83 \%)$ had no training. 
Table.1 Profile characteristics of the tomato growers $n=120$

\begin{tabular}{|c|c|c|c|c|}
\hline \multirow{2}{*}{$\begin{array}{l}\text { Sl. } \\
\text { No. }\end{array}$} & \multirow[t]{2}{*}{ Variable } & \multirow[t]{2}{*}{ Category } & \multicolumn{2}{|c|}{ Respondents (n) } \\
\hline & & & Frequency & Percentage $(\%)$ \\
\hline \multirow[t]{3}{*}{1} & \multirow[t]{3}{*}{ Age } & Young (upto 34 yrs) & 40 & 33.33 \\
\hline & & Middle (35-55 yrs) & 55 & 45.83 \\
\hline & & Old (Above 55 yrs) & 25 & 20.83 \\
\hline \multirow[t]{2}{*}{2} & \multirow[t]{2}{*}{ Marital status } & Married & 107 & 89.16 \\
\hline & & Unmarried & 13 & 10.83 \\
\hline \multirow[t]{5}{*}{3} & \multirow[t]{5}{*}{ Education } & Illiterate & 8 & 6.66 \\
\hline & & Primary (Class I-III) & 50 & 41.66 \\
\hline & & Medium (Class IV-VI) & 35 & 29.16 \\
\hline & & High School (VII-X) & 18 & 15.00 \\
\hline & & Intermediate (X-XII) & 9 & 7.50 \\
\hline \multirow[t]{3}{*}{4} & \multirow[t]{3}{*}{ Family size } & Small size $(1-3)$ & 19 & 15.83 \\
\hline & & Medium size (4 - 6) & 50 & 41.66 \\
\hline & & Large size ( 7 and above) & 51 & 42.50 \\
\hline \multirow[t]{5}{*}{5} & \multirow[t]{5}{*}{ Land holding } & Landless & 19 & 15.83 \\
\hline & & (0.1-1.0 ha) & 64 & 53.33 \\
\hline & & (1.1-2.0 ha) & 24 & 20.00 \\
\hline & & Semi-medium (2.1-4.0 ha) & 10 & 8.30 \\
\hline & & Medium (4.1-10.0 ha) & 3 & 2.50 \\
\hline \multirow[t]{4}{*}{6} & \multirow{4}{*}{$\begin{array}{l}\text { Annual } \\
\text { income * } \\
\text { (Agriculture } \\
\text { +livestock) }\end{array}$} & Low income (up to Rs.17,000) & 24 & 20.00 \\
\hline & & Semi-medium income (Rs.17,001-34,000) & 31 & 25.83 \\
\hline & & Medium income (Rs.34,001-51,000) & 33 & 27.50 \\
\hline & & High income (above Rs.51,000) & 32 & 26.66 \\
\hline \multirow{3}{*}{7} & \multirow{3}{*}{ Extension contact } & Never & 75 & 62.50 \\
\hline & & Regularly & 10 & 8.33 \\
\hline & & Occasionally & 35 & 29.16 \\
\hline \multirow{4}{*}{8} & \multirow{4}{*}{$\begin{array}{l}\text { Social } \\
\text { participation }\end{array}$} & No member of any organization & 80 & 66.66 \\
\hline & & Member of one organization & 20 & 16.66 \\
\hline & & Member of more than one organization & 7 & 5.83 \\
\hline & & Office bearer & 13 & 10.83 \\
\hline \multirow{3}{*}{9} & \multirow{3}{*}{$\begin{array}{l}\text { Economic } \\
\text { motivation }\end{array}$} & Low $(<22.8)$ & 7 & 5.83 \\
\hline & & Medium (22.8-24.2) & 73 & 60.83 \\
\hline & & $\begin{array}{l}\text { High }(>24.2) \\
\text { Mean: } 23.5, \quad \text { SD: } 1.7\end{array}$ & 40 & 33.33 \\
\hline \multirow[t]{3}{*}{10} & \multirow[t]{3}{*}{ Risk Orientation } & Low $(<18.9)$ & 40 & 33.33 \\
\hline & & Medium (18.9-23.3) & 20 & 16.66 \\
\hline & & $\begin{array}{l}\text { High (>23.3) } \\
\text { Mean: 21.1, SD: } 5.2\end{array}$ & 60 & 50.00 \\
\hline \multirow[t]{3}{*}{11} & \multirow{3}{*}{ Training } & No training & 67 & 55.83 \\
\hline & & Regularly & 10 & 8.33 \\
\hline & & Occasionally & 43 & 35.83 \\
\hline
\end{tabular}


Table.2 Reason for participation in training programme

\begin{tabular}{|r|l|l|l|}
\hline $\begin{array}{c}\text { Sl. } \\
\text { No. }\end{array}$ & Reasons & Number & Percentage (\%) \\
\hline 1. Crop improvement & 63 & 52.50 \\
\hline 2. Never participated in training before & 23 & 19.16 \\
\hline 3. Off campus training programme & 20 & 16.66 \\
\hline 4. Just to know about tomato organic cultivation & 8 & 6.66 \\
\hline 5. Market demand & 6 & 5.00 \\
\hline
\end{tabular}

Table.3 Knowledge gain of tomato growers through training programme

\begin{tabular}{|r|l|l|l|l|}
\hline $\begin{array}{c}\text { Sl. } \\
\text { No. }\end{array}$ & Technology practices & $\begin{array}{l}\text { Pre-test } \\
\text { evaluation }\end{array}$ & $\begin{array}{l}\text { Post-test } \\
\text { evaluation }\end{array}$ & $\begin{array}{l}\text { Gain in } \\
\text { knowledge }\end{array}$ \\
\hline 1. & Land preparation & $100(83.33)$ & $120(100.00)$ & $20(16.66)$ \\
\hline 2. & Soil treatment & $00(00.00)$ & $57(47.50)$ & $57(47.50)$ \\
\hline 3. Seed treatment & $04(3.33)$ & $86(71.66)$ & $82(68.33)$ \\
\hline 4. Improved varieties & $08(6.66)$ & $67(55.83)$ & $59(49.16)$ \\
\hline 5. Nursery raising & $78(65.00)$ & $112(93.33)$ & $34(28.33)$ \\
\hline 6. & Transplanting & $90(75.00)$ & $120(100.00)$ & $30(25.00)$ \\
\hline 7. Irrigation management & $70(58.33)$ & $118(98.33)$ & $48(40.00)$ \\
\hline 8. Weed management & $80(66.66)$ & $120(100.00)$ & $40(33.33)$ \\
\hline 9. Nutrient management & $90(75.00)$ & $101(84.16)$ & $11(9.16)$ \\
\hline 10 Plant protection measures & $40(33.330$ & $80(66.66)$ & $40(33.33)$ \\
\hline 11 Harvesting and storage & $80(66.66)$ & $120(100.00)$ & $40(33.33)$ \\
\hline
\end{tabular}

Table.4 Suggestions offered by the trainees for training improvement

\begin{tabular}{|r|l|c|c|}
\hline $\begin{array}{r}\text { Sl. } \\
\text { No. }\end{array}$ & Suggestions & Frequency & Ranking \\
\hline 1. & More importance to training demonstration classes & 96 & I \\
\hline 2. & Disease and insect pest management & 87 & II \\
\hline 3. Post harvest crop management & 80 & III \\
\hline 4. Input crop support & 78 & IV \\
\hline 5. Help to get government subsidy scheme & 76 & V \\
\hline 6. & Supply information printed leaflets/folders & 70 & VI \\
\hline
\end{tabular}

Reason for participation in training programme

The reasons for participation of the tomato growers in training programme were taken based on the ranking importance as perceived by the trainees. Table 2 reported that 52.50 percent participated in training programme mainly due to crop improvement as the farmers used to experience crop damages from diseases, insect pest and storage problems. About 19.16 percent joined training because of never participated in training before which happened due to unawareness of 
training, interior villages and connectivity problems. It was also reported from Table 2 that 16.66 percent of the trainees joined training because of off campus training programme as it was conducted in the village itself which helps the farmers from transportation cost, time constraints and other farming activities could even fulfill before the training session. Less percentage of 6.66 and 5.00 percent joined the training just to know about tomato organic cultivation and market demand in which the similar results were in line with the findings of Suharban et al., (1991) and Kaur (2016).

\section{Knowledge gain of the trainees}

Based on pre-test evaluation on the knowledge level of the trainees about organic cultivation of tomato, the results findings in Table 3 revealed that about 83.33 percent of the trainees had knowledge on land preparation practices followed by transplanting, nutrient management $(75.00 \%$, $75.00 \%)$ and weed management, harvesting and storage $(66.66 \%, 66.66 \%)$ whereas they had zero knowledge on soil treatment $(00.00 \%)$ and less knowledge on seed treatment $(3.33 \%)$ and improved varieties $(6.66 \%)$. On post-test evaluation, the results showed that trainees received a full knowledge $(100.00 \%)$ on land preparation, transplanting, weed management and harvesting and storage followed by irrigation management $(98.33 \%)$ and nursery raising $(93.33 \%)$.

Knowledge gain as shown in Table 3 reported that trainees gained more knowledge on seed treatment $(68.33 \%)$ followed by improved varieties $(49.16 \%)$ and soil treatment (47.50\%).The least knowledge gained by the trainees was on plant protection measures $(3.33 \%)$ and nutrient management $(9.16 \%)$. The reason being the increase in knowledge gain was due to the fact that tomato is the main cash crop for the farmers, high market demand and could supplied daily to the market and it thus contributes to farmers' major income fetching handsome price especially during off season.

\section{Suggestions offered by the trainees for training improvement}

The results in Table 4 showed that the suggestions offered by more than half of the trainees for further improvement of the training course were more importance to training demonstration classes, disease and insect pest management, post-harvest crop management, input crop support, government subsidy scheme and supply information printed leaflets/folders. This was due to the fact that 45.83 per cent of the trainees belonged to middle age group (35-55 yrs) and 20.83 percent old age group (above 55 yrs) which brings a tendency among the trainees to acquire and retain more knowledge through seeing rather than listening. Also the major problems faced by the trainees were on disease and insect pest management where they had to purchase $\mathrm{kg}$ of chemical pesticides every season to control them. Similarly, due to price fluctuation the perishability of the crop produces resulted to distress sale and a great loss to the tomato growers.

From the study, we can conclude that training programme plays a major role in shaping and strengthening the knowledge of the trainees and thus helps to adopt the relevant farm technology in the future. Organic farming of tomato would help the farmer to reduce the cost of cultivation, dependency on chemical pesticides and would create a scope opportunities for the tomato growers to export venture business. It thus paves the way for sustainable farming and overall brings prosperity and healthy living for the farming community. 


\section{References}

Fakoya, E. O., and Olonintoba, A. 2003. The socio-economic indicators of adult females in rural communities of Nigeria, J. Ext. Sys., 19(2):48-52.

GoM, 2018.Area, Production \& Yield of Horticultural Crops of West Khasi Hills District 2017-18.Department of Agriculture, Government of Meghalaya, Shillong. http://megagriculture.gov.in. Data accessed: November 20, 2019.

Helen,S., and Khaleel, F.M.H.2009. Development of a scale to measure the information efficiency of agricultural expert system. Ind. J. Ext. Edu.,45(3 \& 4):137-140).

Kaur,K.2016. Impact of Training Course on Knowledge Gain of Mushroom Trainees. J. Krishi Vigyan.4(2) : 54-57.

Manay, S., and Farzana, C.2000. Socioeconomic characteristics of rural family, Maharashtra J. Ext. Edu.,19: 325-328.

Suharban, K., Rahman, O., and Nair, M. C.1991. An evaluation of mushroom cultivation course. Ind. J. Ext. Edu.,27(3-4): 118-121.

\section{How to cite this article:}

Marbaniang, E. K., J. K. Chauhan and Pynbianglang Kharumnuid. 2021. Impact of Training Programme on Knowledge Gain of Tomato Growers in Meghalaya. Int.J.Curr.Microbiol.App.Sci. 10(01): 2569-2574. doi: https://doi.org/10.20546/ijcmas.2021.1001.298 